and pointed towards my blind and then headed in its direction. It looked as if my hide-out would be their second stop. I watched them pick their way carefully around the slough in an effort to keep their shoes dry. There were four and they ranged in age from five to eight. As they came closer I heard one say, "It looks like it's made of cardboard" and other indecipherable remarks. As they got within speaking distance, the boy of the group boldly said, "Anybody home?" I had withdrawn my telephoto lens as the boy was carrying a stick and I didn't know just what to expect. He said again, "Anybody there?" to which I answered with a "Yes!" I guess they didn't expect the blind to be, inhabited, and with a few startled gasps they took to their heels and didn't stop until they got back up on the ridge some distance from the bus. Nor did they pick their way carefully around the slough, but headed straight through the middle. It was the most direct route towards home. Home I believe was their third stop. I guess I was as surprised as they at this reaction and I chuckled as I looked out of the peep-hole and saw them splashing their way through the slough.

Spring on the prairies comes late. Bursting tree buds and a lush growth of grass are not visible until late May. But the first signs of Spring are evident in April and I noted Flickers arriving daily for a brief stop-over in migration, as many as a dozen being seen at one time clumsily walking over the hay meadow, or flitting through the trees. Western Meadowlarks were singing from vantage points.

In North Dakota another booming ground was visited where the birds executed their elaborate and interesting mating ritual on newly ploughed land, an adaptation that was unexpected. Wherever their booming grounds may be, the birds all seem to leave their chosen spot soon after day-break.

Formerly found from the Atlantic States through the Great Plains of North America, they are now confined largely to the Great Plains regions. This is the bird to which, by precedence and by custom, rightfully belongs the name Prairie Chicken. From the long feathers on its neck it has also received another namePinnated Grouse. And to distinguish it from the Sharp-tailed Grouse, it is sometimes called the Square-tail. It is larger and darker than the Sharptail and the inflated air sacs, seen only during the dancing ritual, are a vivid orange rather than lilac as in the Sharp-tail.

In my notes of birds seen on this thoroughly enjoyable holiday, Marsh Hawks predominate. A rather remarkable flight of Snow Buntings was witnessed west of Winnipeg, where several flocks containing thousands of these birds flew across the ploughed fields. The fields were a rich black, still wet from the melting winter snows, and against this background the "snow birds" made a charming sight, looking like large fluffy snowflakes that come with a spring snowstorm. The warm welcomes with which I was everywhere received contrasted sharply with the exceptionally cold April weather, and I am indeed most grateful to the many folks who helped me in so many ways on this trip.

\section{DETERMINED DANCERS}

\section{By Lindsay Wotherspoon, Crestview, Man.}

We have a Sharp-tailed dancing ground on our farm and 20 to 25 birds congregated there last spring. As I was seeding the field on May 27, 1959, I seeded right through their acre-sized "dance hall," but they did not interrupt their manoeuvres except to keep out of the way of the tractor and drill. I watched the birds so intently that I made some pretty crooked seed rows.

Our farm is at the northern edge of settlement, on the edge of the Porcupine Mountains, 20 miles north and four miles east of Arran, and just one and a half miles west of the Manitoba border ( $\mathrm{N} 1 / 2$ 11, T.37, R. 30, W. 1). The farm is really in Saskatchewan though we get our mail at a Manitoba post office, Crestview. 